\title{
PNEUMONIA, O PROVOCARE CONTINUĂ PENTRU PEDIATRU - PREZENTARE DE CAZ
}

\author{
Maria Oana Mărginean', Cristina Oana Mărginean ${ }^{1,2}$, Vlăduţ Săsăran', \\ Nicoleta Suciu' ${ }^{1}$, Lorena Elena Meliţ ${ }^{1,2}$ \\ ${ }^{1}$ Universitatea de Medicină şi Farmacie, Târgu Mureş \\ ${ }^{2}$ Clinica de Pediatrie Nr. 1, Târgu Mureş
}

\begin{abstract}
REZUMAT
Pneumonia reprezintă o inflamaţie a parenchimului pulmonar care, în ciuda multiplelor clase de antibiotice disponibile şi în ciuda progreselor medicinei, deţine încă o rată crescută de mortalitate, mai ales în cazul copiilor. Deltfia acidovorans şi Stenotrophomonas maltofilia sunt bacili Gram-negativi care pot determina infecţii respiratorii. Prezentăm cazul unui pacient de sex masculin, în vârstă de 2 ani şi 3 luni, internat în clinica noastră pentru următoarele motive: tuse productivă, febră şi inapetenţă. Pe baza examenului obiectiv, a analizelor de laborator şi a investigaţiilor imagistice, am stabilit diagnosticul de pneumonie dreaptă asociată cu pleurezie şi am instituit antibioterapie cu spectru larg. Evoluţia a fost însă nefavorabilă, pacientul necesitând pleurostomie şi drenaj. Din lichidul pleural au fost izolaţi Delftia acidovorans şi Stenotrophomonas maltophilia. Am modificat schema de tratament conform antibiogramei, cu evoluţie ulterioară lent favorabilă. Particularitatea cazului constă în diagnosticarea unei pneumonii cu pleurezie la un copil în vârstă de 2 ani şi 3 luni, cu un episod de pneumonie în antecedente, fără factori de risc, care a necesitat pleurostomie cu drenaj toracic, la care cultura din lichidul pleural a evidenţiat doi germeni întâlniţi de obicei la persoanele imunocompromise, cu evoluţie favorabilă după iniţierea antibioterapiei conform antibiogramei.
\end{abstract}

Cuvinte cheie: pneumonie, copil, pleurezie, Delftia acidovorans,

Stenotrophomonas maltophilia

\section{INTRODUCERE}

Infecțiile de tract respirator sunt una din cele mai frecvente patologii întâlnite în practica pediatrică, împărțindu-se în funcție de localizare în infecții ale căilor aeriene superioare și infecții ale căilor aeriene inferioare. Majoritatea sunt forme ușoare, uneori auto-limitante, astfel că de multe ori sunt neglijate (1). Pneumonia face parte din categoria infecțiilor de căi aeriene inferioare și reprezintă inflamația parenchimului pulmonar, care în lipsa tratamentului poate duce la diferite complicații precum pleurezia meta- sau parapneumonică, abces pulmonar, abcedare cu empiem pulmonar, care de foarte multe ori pot fi fatale.
Delftia acidovorans, anterior numit Comamonas acidovorans sau Pseudomonas acidovorans este un bacil aerob, Gram-negativ, non-fermentativ, mobil, cu flageli la unul sau ambii poli (2). Acest bacil este ubicuitar, fiind întâlnit în sol, apă și mediul de spital, putând afecta atât persoanele imunodeprimate, cât și pe cele imunocompetente (3). Delftia acidovorans poate fi izolată din tractul respirator, ochi și sânge, însă de foarte puține ori prezintă relevanță clinică (4). Cu toate acestea, în cazul pacienților imunocompromiși, cu neutropenie, acest bacil poate cauza infecții cu răsunet clinic major (3). Deși aminoglicozidele reprezintă clasa de antibiotice folosită de primă intenţie în cazul infecțiilor cu germeni Gram-negativi, Delftia

Autor corespondent:

Cristina Oana Mărginean, Universitatea de Medicină şi Farmacie, Str. Gh. Marinescu nr. 38, Tîrgu Mureş, 540136

E-mail: marginean.oana@gmail.com 
acidovorans este de cele mai multe ori rezistent la aminoglicozide (5), astfel că izolarea acestuia este esențială în vederea administrării unei antibioterapii țintite.

Stenotrophomonas maltophilia, denumită în trecut Pseudomonas maltophilia, este un germen aerob, Gram-negativ, ubicuitar, multi-drog rezistent (6). Cel mai adesea, Stenotrophomonas maltophilia crește în apa potabilă, prezentând un risc crescut de infecție, mai ales pentru pacienții imunocompromiși (6). Acest patogen este cel mai adesea asociat cu infecții de tract respirator la oameni, însă poate cauza de asemenea infecții oculare, endocardită, sepsis biliar, infecții ale oaselor și articulațiilor, infecții de tract urinar și de asemenea, meningită (6). Majoritatea pacienților cu infecții determinate de Stenotrophomonas maltophilia sunt pacienți cu comorbidități, precum neoplazii, boli cronice pulmonare sau imunodepresie (6). Tratamentul infecțiilor respiratorii cauzate de Stenotrophomonas maltophilia este foarte dificil, atât din cauza rezistenței intrinseci a acestui germen la un număr mare de antibiotice, cât și a abilității sale de a dezvolta rezistență pe parcursul tratamentului antibiotic $(7,8)$. Cu toate acestea, fluorochinolonele sunt antibioticele utilizate de rutină în cazul acestor pacienți (9). Din cauza folosirii la scară largă a acestei clase de antibiotice, precum și a antibioticelor în general, rezistența acestui bacil gram negativ devine tot mai mare, cauzând infecții nosocomiale tot mai severe, de cele mai multe ori cu risc vital. Prin urmare, izolarea bacteriei și cultivarea acesteia dețin un rol major în managementul pacienților cu diferite infecții cauzate de Stenotrophomonas maltophilia.

\section{PREZENTARE DE CAZ}

Prezentăm cazul unui pacient de sex masculin în vârstă de 2 ani și 3 luni, care a fost internat în clinica noastră acuzând tuse productivă, inapetență și febră de aproximativ 5 zile. Antecedentele heredo-colaterale nu au fost relevante pentru patologia actuală. Din antecedentele personale patologice, a reieșit faptul că la vârsta de 1 an, pacientul a prezentat un episod de pneumonie comunitară, probabil bacteriană, pentru care a primit tratament ambulator. Patologia actuală a debutat în urmă cu aproximativ 5 zile anterior internării, cu febră, tuse productivă și inapetență, motive pentru care medicul de familie recomandă tratament antibiotic (cefalosporină de generația a doua) din cauza persistenței febrei, și simptomatic, însă fără remiterea simptomatologiei, astfel că s-a internat în clinica noastră pentru investigații și tratament de specialitate.

Examenul obiectiv efectuat în momentul internării a evidenţiat următoarele elemente patologice: stare generală influențată, febră $\left(38,7^{\circ} \mathrm{C}\right)$, facies suferind, tegumente palide, calde, faringe și amigdale hiperemice, tuse productivă, murmur vezicular diminuat pe partea dreaptă, raluri crepitante diseminate pe întregul câmp pulmonar drept, ușoară tahicardie (100 bătăi/minut), greutate $12 \mathrm{~kg}$. Analizele de laborator efectuate în ziua internării au relevat următoarele: ușoară leucocitoză cu netrofilie (Leu 10.980/ $\mathrm{mm}^{3}$, Neu 7.990/mm3), anemie (Hb $11 \mathrm{~g} / \mathrm{l})$, transaminaze crescute (AST 94,4 U/L, ALT 110,2 U/L), viteză de sedimentare a hematiilor crescută (VSH 120 $\mathrm{mm} / \mathrm{h}$ ), proteina $\mathrm{C}$ reactivă crescută (PCR 35 $\mathrm{mg} / \mathrm{l})$. Frotiul periferic a demonstrat o deviere la stânga cu predominanța segmentatelor (74\%), precum și a prezenței granulațiilor toxice și a vacuolelor la nivelul polimorfonuclearelor. Am efectuat de asemenea investigații imagistice. Astfel, ecografia abdominală a pus în evidență existența unei cantități minime de lichid în sinusul costo-diafragmatic drept; radiografia abdominală a arătat opacități multiple la nivelul lobilor mijlociu și inferior ai plămânului drept, cu pleurezie închistată la nivelul scizurii oblice (Fig. 1).

Am efectuat de asemenea CT toracic în a doua zi de spitalizare, care a evidențiat pleurezie bazală dreaptă cu o grosime de aproximativ 18 mm, închistată paracardiac și latero-bazal la nivelul lobului mijlociu drept. Astfel, am stabilit 


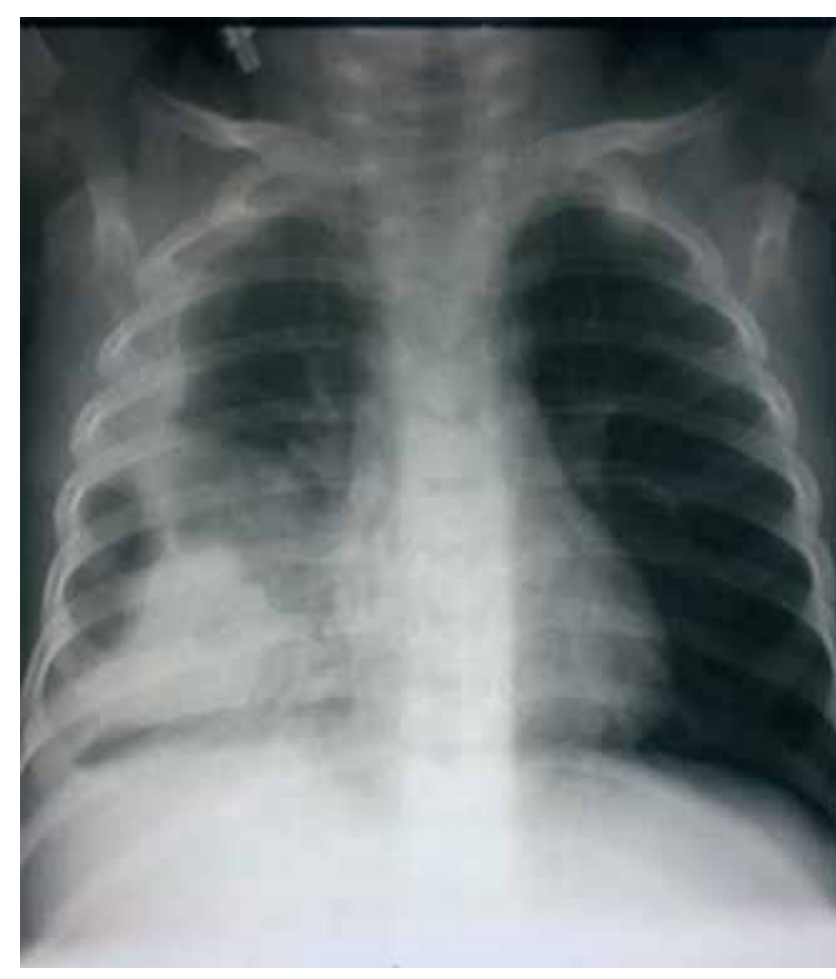

Figura 1. Aspect radiologic al plămânului drept în momentul internării

diagnosticul de pneumonie comunitară, bacteriană, cu pleurezie dreaptă, precum și sindrom de hepatocitoliză. Diagnosticul diferenţial a inclus: procese expansive pulmonare (excluse prin CT), aspirație de corp străin/conținut gastric (excluse prin anamneză și investigații paraclinice), pneumonii de altă etiologie (excluse prin investigațiile imagistice și cultura din lichidul pleural), embolia pulmonară (exclusă pe baza tabloului clinic și investigațiilor imagistice), edemul pulmonar (exclus pe baza tabloului clinic și investigațiilor imagistice), bronșiectazia abcedantă (exclusă pe baza anamnezei și a investigațiilor imagistice), și chistul hidatic (exclus pe baza analizelor de laborator, investigațiilor imagistice și culturii din lichidul pleural). Astfel, am iniţiat tratament antibiotic: Meropenem $240 \mathrm{mg}$ de 3 ori pe zi și Teicoplanin $120 \mathrm{mg}$ de 2 ori pe zi timp de 5 zile, precum și simptomatic, și anume: antipiretice, analgezice, hepatoprotectoare, gastroprotectoare, precum și probiotice. Evoluția însă a fost nefavorabilă, din cauza persistenței febrei și a stării generale alterate. Astfel în a 5-a zi de spitalizare, s-a efectuat pleurostomie cu drenaj toracic. Examenul bacteriologic efectuat din lichidul pleural a pus în evidență multe leucocite, precum și eritrocite. Cultura a identificat doi germeni, și anume: Delftia acidovorans, sensibil la majoritatea cefalosporinelor și Stenotrophomonas maltophilia, sensibil la Trimetoprim/Sulfametoxazol și Levofloxacină. Astfel, schema terapeutică a fost modificată conform antibiogramei, cu administrarea de Ceftazidime $600 \mathrm{mg}$ de 2 ori pe zi asociat cu Levofloxacină $120 \mathrm{mg}$ de 2 ori pe zi timp de 17 zile, asociind de asemenea și antifungic timp de 5 zile, Fluconazole $70 \mathrm{mg}$ în prima zi de internare, iar ulterior 35 mg în următoarele 4 zile. Evoluția ulterioară a fost lent favorabilă, cu remiterea treptată a febrei și ameliorarea stării generale, tubul de dren fiind îndepărtat în ziua a 15-a de spitalizare. Tratamentul antibiotic a fost continuat timp de 21 de zile, cu normalizarea analizelor de laborator. Înainte de externare, am repetat de asemenea radiografia toracică, punând în evidență pahipleurită dreaptă. Pacientul a fost externat în stare generală bună, cu recomandarea de a continua tratamentul hepatoprotector timp de o lună și de a recurge de urgență la consult pediatric în cazul unei simptomatologii sugestive pentru o pneumonie (Fig. 2).

Particularitatea cazului constă în diagnosticarea unei pneumonii comunitare, bacteriene, cu pleurezie la un copil în vârstă de 2 ani și 3 luni, cu un episod de pneumonie în antecedente, care provine dintr-un mediu favorabil, necesitând pleurostomie cu drenaj toracic, la care cultura din lichidul pleural a evidențiat doi germeni întâlniţi de obicei la persoanele imunocompromise, cu evoluţie favorabilă după iniţierea antibioterapiei conform antibiogramei.

\section{DISCUTIII}

Infecțiile de căi aeriene inferioare sunt una din principalele cauze de mortalitate și morbiditate în întreaga lume (10). Infecțiile de tract respirator cauzează 34.6\% decese în Asia de SudEst, din totalul de 3.941 .000 de decese din lume (11). Etiologia acestor infecții variază cu vârsta, 


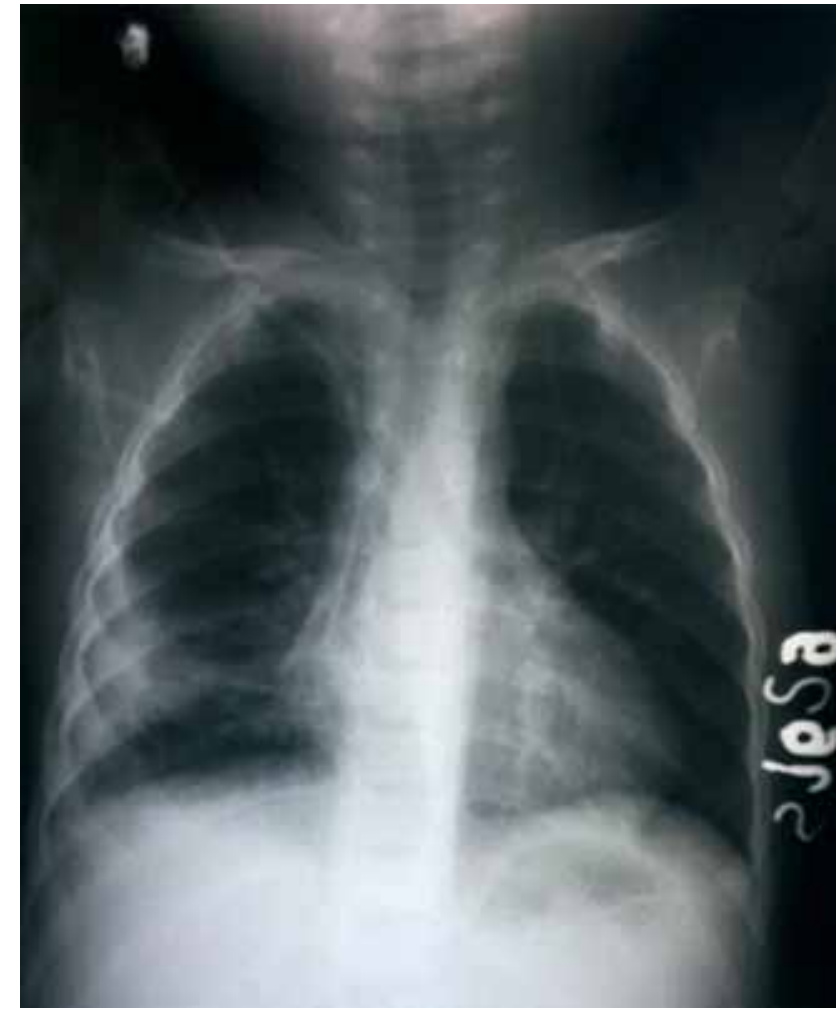

Figura 2. Aspect radiologic al plămânului drept în momentul externării

genul, sezonul, particularităţile individuale ale statusului imunologic, dar și în funcție de alți factori (12). Cu toate că etiologia infecțiilor de tract respirator nu poate fi determinată clinic, în funcție de acești factori menționați mai sus, medicul se poate orienta spre o anumită etiologie posibilă în vederea administrării unei terapii antibiotice cât mai țintite până în momentul izolării agentului cauzator, când este posibil.

Delftia acidovorans este un bacil Gram-negativ ubicuitar care poate cauza infecții de tract respirator, afectând atât persoanele imucompetente, cât și pe cele imunocompromise (3). Cu toate că incidența este rară iar relevanța clinică nu este semnificativă în majoritatea cazurilor, în cazul pacienților imuncompromiși, cu neoplazii, boli cronice renale, HIV/SIDA sau pacienți care se află pe tratament cronic imunosupresor, această bacterie poate provoca infecții severe (13). În ciuda severității și a evoluției lent favorabile, în cazul pacientului prezentat mai sus nu am identificat nici un semn clinic sau paraclinic de status imunologic compromis. Un studiu recent efectuat într-o unitate de terapie intensivă din Brazilia a izolat 24 de tulpini de Delftia acidovorans la 21 de pacienți din probele obținute prin aspirat traheal, însă nu au putut determina relevanța clinică a acestei bacterii din cauza lipsei datelor clinice și a posibilității de a urmări acești pacienți (14). Din cele 24 de tulpini, nici una nu a fost sensibilă la polimixină B, amikacină, gentamicină sau tobramicină, iar fluorochinolonele și biseptolul au prezentat activitate variabilă împotriva tulpinilor izolate (14). Evoluţia infecțiilor respiratorii determinate de acest bacil Gram-negativ este imprevizibilă atât în cazul pacienților imunocompromiși, cât și în cazul pacienților imunocompetenți. Astfel, Khan et al a descris cazul unui copil în vârstă de 4 ani, imunocompetent, care a fost diagnosticat cu empiem determinat de Delftia acidovorans. În ciuda tratamentului antibiotic administrat conform antibiogramei, pacientul nu a supraviețuit (15). Chun et al a raportat de asemenea un caz de empiem cronic determinat de Delftia acidovorans la un pacient adult imunocompetent (16). Din fericire, pacientul nostru a prezentat evoluție favorabilă după administrarea antibioticelor conform antibiogramei.

Stenotrophomonas maltophilia, un bacil Gramnegativ oportunist, este un agent cauzator important al infecțiilor nosocomiale, dar nu numai, mai ales în cazul indivizilor imunocompromiși (17). Factorii care predispun la infecție cu Stenotrophomonas maltophilia includ: prezența cateterelor venoase centrale, a sondelor urinare, ventilația mecanică, neoplazii, chirurgie recentă, internarea într-o secție de terapie intensivă, medicație imunosupresoare, neutropenia, precum și utilizarea antibioticelor în antecedentele recente $(18,19)$. Nici unul din acești factori nu a fost identificat în cazul pacientului descris de noi. Acest bacil prezintă multiple mecanisme de apărare și a dezvoltat rezistență împotriva mai multor clase de antibiotice, inclusiv carbapeneme, iar utilizarea la scară largă a antibioterapiei a dus la transformarea acestuia într-un 
patogen predominant nosocomial (20). Cu toate acestea, trimetoprimul-sulfametoxazol este tratamentul de elecție pentru infecțiile cauzate de Stenotrophomonas maltophilia, iar fluorochinolonele reprezintă alternativa (21). Similar celor menţionate mai sus, în ciuda administrării unui antibiotic din clasa carbapenemelor, inițial, evoluția pacientului nostru a fost nefavorabilă, însă odată cu introducerea unei fluorochinolone, simptomatologia s-a remis treptat. Totuși, odată cu utilizarea tot mai frecventă a fluorochinolonelor, rezistența la această clasă de antibiotice începe să crească și ea, astfel obligând medicul să utilizeze judicios antibioterapia, și pe cât posibil, să ajusteze tratamentul în funcție de antibiogramă.

\section{CONCLUZII}

Delftia acidovorans şi Stenotrophomonas maltophilia sunt doi germeni Gram-negativi care cauzează în principal infecţii de tract respirator. $\mathrm{Cu}$ toate că infecţiile cauzate de ambii germeni au fost descrise atât la persoanele imunocompetente, cât şi la cele imunodeprimate, se pare că severitatea este mult mai mare la imunocompromişi. Asocierea dintre cei doi germeni poate determina o infecţie cu risc vital în cazul copiilor. 